\title{
O Pacto Federativo
}

Brasileiro e a Polêmica da

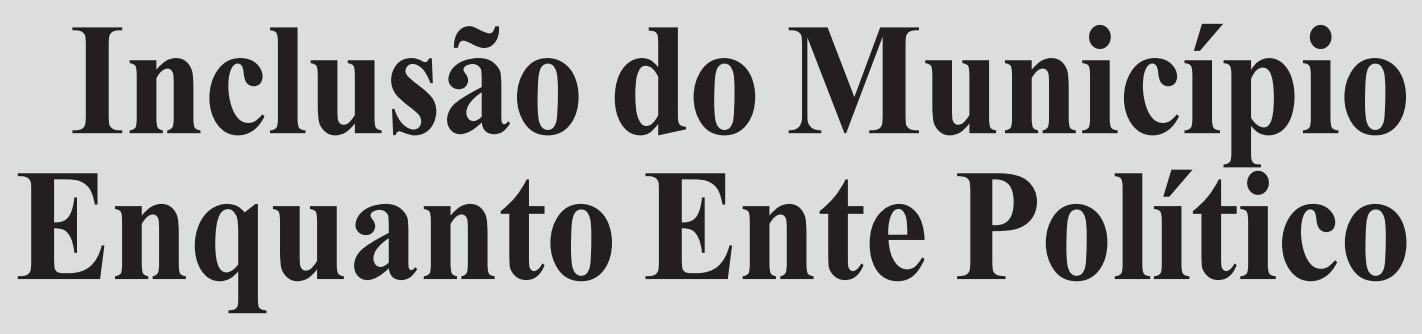

\section{Francisco Jório Bezerra Martins}

Bacharel em Direito, pela Unifor - Universidade de Fortaleza; Especialista em Direito Público pela UFPE - Universidade Federal de Pernambuco, Especialista em Direito Público pela Faculdade de Direito de Coimbra, Mestrando em Direito pela Faculdade de Direito de Coimbra, Professor de Direito Constitucional, Estrutura do Estado Federativo da Unifor. 



\section{O Pacto Federativo Brasileiro e a Polêmica da Inclusão do Município Enquanto Ente Político}

A organização política administra brasileira adota o modelo ímpar de conceber aos Municípios a qualidade de ente da federação. Está, ao menos em teoria, no mesmo degrau hierárquico ao lado dos Estados-membros, e da União federal. Modelo ímpar!

Temos assim que o Município faz parte do pacto federativo, ao lado da União, Distrito Federal e dos Estados-membros

Como ente público federado, o Município brasileiro é dotado de autonomia política, administrativa, financeira e tributária; deve obediência aos princípios constitucionais, inclusive aqueles cristalizados nas constituições Estaduais, além de respeitar a legislação outorgada no âmbito da competência dos demais componentes da federação.

Quando por algum motivo a harmonia existente entre essas pessoas jurídicas de Direito Público interno é abalada, ou melhor, quando algum ente da federação incorre em alguma das hipóteses previstas na Constituição Federal, autorizadoras do procedimento especial e extraordinário, surge a oportunidade de deflagrar a intervenção, com o fito de devolver à Federação, a ordem jurídica e unidade nacional.

O presente e despretensioso trabalho é fruto de um estudo comprometido com a fidelidade acadêmica de despertar o senso crítico de vários estudiosos dos diversos calibres. Apesar de apontar um posicionamento que incomoda consagrados e renomados autores, não nos furtamos de filiarmos a uma corrente que defende a modificação do pacto federativo brasileiro, no sentido de aprimorar nossa forma de Estado, democratizando ainda mais a participação popular, notadamente a população local ao acesso ao poder político. Sabe-se pois que a municipalidade é o maior contato de uma comunidade com o já mencionado poder político. 
Seria bastante presunçoso dizer que nas linhas a seguir reproduzidas, a matéria estará plenamente esgotada. É um desiderato inatingível. Trata-se apenas de um estudo realizado com maior acuidade, cuja atualização deverá ser constante, seja através do debate, leitura ou alterações normativas bem como críticas construtivas.

Destarte, espero que ao oferecer essa contribuição, reconhecidamente modesta, as discussões respeitantes às matérias aqui versadas, sejam mais uma vez erguidas, e com isso, a comunidade jurídica desperte para a riqueza do debate acadêmico existente no Brasil.

\section{IO Conceito de Estado Federal}

A etimologia do termo 'federal' provém do latim foedus, foederis, e significa aliança, pacto, união. Destarte, o Estado Federal deriva da composição de Estados menores, de uma união de Estados.

Pela doutrina clássica os Estados podem ser qualificados, quanto à sua forma, entre simples ou compostos, cuja determinante será o mecanismo de centralização e descentralização do poder político, bem como o exercício da soberania. Os Estados simples ou unitários são aqueles que possuem apenas um centro político, expoente do sistema jurídico, comportando apenas uma legislação uniforme para todo o território. No Estado unitário pode ocorrer descentralização administrativa, mas jamais descentralização política, o que provocaria uma secção por gerar o nascimento de outra pessoa jurídica de direito público interno. Com efeito, nessa modalidade de Estado os Municípios ou Regiões são consideradas tão somente descentralizações administrativas territoriais, criaturas do Poder Central com competências e prerrogativas atribuídas por lei emanada deste, ausente qualquer sorte de autonomia política, a não ser de cunho regulamentar, do que lhe for concebido.

Por sua vez, os Estados compostos podem ser do tipo federado, ou confederados. Passemos a distinguir entre Confederação (do latim confoederatio, confoederare) e Federação. Entendemos Confederação como a união entre dois ou mais Estados soberanos, com objetivo de perseguir um bem comum para o conjunto, resguardando, no entanto, a liberdade de se autogovernar. Geralmente os Estados confederados nascem por celebração de tratados internacionais, sem ocasionar o surgimento de um novo Estado, 
mas sim uma sociedade internacional, podendo ser desfeita, ou até mesmo reduzida, pela rescisão de qualquer dos contratantes. São exemplos de Confederações: a Suíça, até 1848, a Germânica de 1815, e os Estados Unidos da América do Norte, de 1776 a 1787. A Convenção da Filadélfia encerrou a experiência confederada norte-americana, que durou 11 anos, durante os quais sobreviveram treze unidades soberanas, treze soberanias internas advindas da celebração de tratado internacional, portanto, dissolúvel por qualquer das partes, a qualquer tempo. Cada unidade confederada podia negociar livremente com as demais nações soberanas mundiais, obter empréstimos internacionais sem a necessidade de qualquer autorização da União americana, fosse pelo Tesouro Nacional, ou da Câmara Alta, posto que esta mesma União era desprovida de soberania.

A Federação é composta por um conjunto, congregação ou aliança de Estados-membros, desprovidos de soberania, contudo, dotados de autonomia política e administrativa, cuja totalidade da coletividade, essa sim, possui soberania. Trata-se de uma sociedade de Estados, onde existe uma pluralidade de legislação e administração de cada unidade autônoma, sendo estas respeitantes dos princípios e regras gerais estabelecidas na Constituição da Federação. Cada Estado-membro promulga sua própria Constituição Estadual, elege seus dirigentes e também os integrantes da sua respectiva Casa legislativa.

Essa união de Estados federados pode ocorrer de sua composição histórica e real, ou por força de norma, criação jurídica. O primeiro caso surge quando Estados preexistentes dão origem ao Estado Federado; o segundo, quando um documento jurídico seciona um território em distintas frações, denominadas Estados, no ato da composição do Estado Federal. Em ambos casos, aglutinação, ou por secessão, cumpre salientar que a Constituição Federal é o documento hábil para formalizar a existência do Estado Federal, sendo o seu instrumento jurídico-positivo fundamental para a sua existência.

Para exemplificar a primeira hipótese, agregação de Estados preexistentes, podemos mencionar o caso dos Estados Unidos da América do Norte. A federação norte-americana derivou da independência das 13 ex-colônias inglesas que se fundiram dando origem aos Estados Unidos da América do Norte. Após a fusão, consagraram a Constituição Federal, impondo a superioridade da União, face à Constituição dos Estados. Para concretizar essa unificação, cada Estado-membro abriu mão de uma parcela de seu poder 
repassando-o para a União. Como exemplo da segunda hipótese citamos o Brasil, quando a Constituição Republicana de 1891, aproveitando-se da divisão territorial das províncias, elegeu-as à categoria de Estados, congregados na União Federal.

Note-se, pois, que a principal diferença para o federalismo dos americanos do norte, é que ao compor o brasileiro, não houve fusão de Estados, e sim a secessão de um todo, cujo esboço era a já divisão do Estado unitário em províncias, formalizados pela feitura da Constituição, instrumento que o concebeu.

Terminadas essas considerações iniciais, chegamos inevitavelmente à conclusão de que o fim perseguido pelo estabelecimento da forma federativa, é o de descentralizar a administração. A descentralização promovida pela federação é a de cunho administrativa e política. Com isso, administrativamente implica afirmar da subtração de competências de um centro, e fazer passá-las a outro, adotando-a como sua, independentemente dos demais; e, politicamente, a capacidade de criar norma legal sobre matéria de sua responsabilidade.

Com base na distinção entre centralização e descentralização políticas no território de uma organização estatal, é possível elaborar uma distinção entre Estado Unitário e Estado Federal, ainda que aquele apresente um elevado nível de descentralização. O princípio federativo cristaliza o conceito de uma forma de descentralização do poder estatal no âmbito de seu território, buscando uma harmonia na coexistência de várias ordens jurídicas parciais com uma ordem jurídica central. Federalizar um Estado, significa tornar independentes determinadas unidades políticas territoriais ${ }^{1}$, que até um determinado momento não possuíam autonomia dentro da organização estatal.

As relações entre os Estados-membros e o governo central evidenciam que o federalismo foi ditado por razões práticas, notadamente com a convivência harmoniosa e pacífica de aglomerações sócio-políticas presentes em um mesmo território. Essas aglomerações tinham em vista a participação igualitária no processo decisório do governo, mas na qualidade de Estados-membros, abriam mão da soberania 'local' em prol da formação do todo político, da soberania unificadora ${ }^{2}$.

\footnotetext{
${ }^{1}$ LUCAS VERDÚ, Pablo. Curso de derecho político. Vol. II., Madrid: Tecnos, 1986, p. 277.

${ }^{2}$ GARCÍA-PELAYO, Manuel. Derecho constitucional comparado. Madrid:Alianza, 1993, p. 215.
} 
Pinto Ferreira trouxe à baila uma conceituação de federalismo que, apesar de anterior à nossa Carta que erigiu os Municípios a iguais entes federados, vale a pena colacionar, diz o professor:

O Estado Federal é uma organização, formada sobre a base de uma repartição de competências entre o governo nacional e os governos estaduais, de sorte que a União tenha a supremacia sobre os Estados-Membros e estes sejam entidades dotadas de autonomia constitucional perante a mesma União. ${ }^{3}$

José Tavares ${ }^{4}$ adverte para a inexistência de um conceito unívoco de federalismo, sendo "uma realidade variável no espaço, no tempo e em grau", "sendo, nalguns casos, associados, total ou parcialmente, a realidades afins, tais como descentralização, Estado unitário regional, integração e outras”.

O federalismo é uma espécie de descentralização política ao fragmentar ou reconhecer a divisão de um território em coletividades territoriais dotadas de autonomia política, mas desprovidas de soberania, que é entregue à união dos Estados, que formará o Estado Federado. Inicialmente definiremos descentralização como a distribuição de competências de um centro para atribuí-las a outro, passando estas a serem próprias do novo centro. No capítulo seguinte nos estudaremos mais este conceito em suas diversas matizes. De ante mão esclarecemos ainda que esta descentralização quando operada relativamente aos Estados federados, é do tipo administrativa e política, posto que confere aos integrantes do pacto federativo a capacidade de se autogovernarem, e ainda atribui competências legislativas, todas em obediência à ordem constitucional nacional. Sobre este tema, Kelsen aponta que

[...] idealmente, uma comunidade jurídica centralizada é aquela cujo ordenamento consta única e exclusivamente de normas jurídicas que valem para todo o território do Estado, enquanto uma comunidade jurídica descentralizada é, idealmente, aquela cujo ordenamento consta de normas que apenas vigoram para domínios (territoriais) parcelares. Dizer que uma comunidade jurídica se desmembra em regiões ou parcelas territoriais significa que todas as normas ou apenas certas normas deste ordenamento apenas

${ }^{3}$ FERREIRA, Luiz Pinto. Princípios gerais do direito constitucional moderno. vol. II, $6{ }^{a}$ ed., São Paulo: Saraiva, 1983, p. 909.

${ }^{4}$ TAVARES, José. Estudos jurídico-políticos. Lisboa: Universidade Autónoma de Lisboa, 1996, p. 19. 
vigoram para territórios parcelares. Neste último caso, a ordem jurídica que constitui a comunidade jurídica é integrada por normas com diferentes âmbitos espaciais de validade ${ }^{5}$.

A complexidade de um Estado federal exige especial atenção por parte do legislador constituinte, face a necessidade de organizar o poder político nacional. No momento inicial "há que repartir as atribuições (e correspondentes poderes) entre a União e os Estados federados; em segundo lugar, tem de proceder-se à atribuição de poderes aos órgãos criados em cada um daqueles níveis (união e Estados federados)" ${ }^{\text {" }}$.

A divisão de competências pode ocorrer de três maneiras: a) o critério de enumerar a competência da União e dos Estados-membros; b) o critério de enumerar a competência dos Estados, e estabelecer que o resíduo, ou seja, aquela matéria não atribuída ao Estado passa a ser de responsabilidade da União; c) o critério de enumerar a competência da União, deixando residual a competência dos Estados.

Face a esse conglomerado de conceitos e características, podemos indicar alguns traços essenciais para a formação do federalismo: a) devido ao pacto celebrado entre os Estados-membros para a formação do Estado Federal, estes são detentores apenas de autonomia, ao passo que a soberania passa a ser exercida exclusivamente pelo o Estado Federal; b) o pacto deve ser selado por uma Constituição rígida, na qual devem constar expressamente as competências dos Estados-membros, assim como o mecanismo para assegurar a continuidade da harmonia do Estado Federal, ou seja, a intervenção; c) os Estados-membros devem ter assento no legislativo nacional, participar do processo de formação da vontade do Estado soberano e, finalmente, d) existência de uma corte suprema que tenha o compromisso de proteger e interpretar a Constituição, resolvendo os conflitos de competência entre a União e os Estados-membros, ou entre os próprios Estados-membros entre si.

\footnotetext{
${ }^{5}$ KELSEN, Hans. Teoria pura do direito. tradução: João Baptista Machado, 6 ed., São Paulo: Martins Fontes, 1998, p. 348.

${ }^{6}$ TAVARES, José. Op. cit. p. 50.
} 


\section{ANTECEDENTES E FORMAÇÃo do ESTAdo FEDERAdO}

Há de se descrever algumas passagens inarredáveis para a construção do federalismo nacional. Verificava-se no período Imperial o experimento malogrado das Capitanias Hereditárias, que por fatores tais como resistência dos índios em serem escravizados, secas, falta de recursos financeiros e humanos, ausência de comunicação com os donatários e a realeza, dentre outros tantos motivos, contribuíram para que cada uma se desenvolvesse dentro das possibilidades humanas e geográficas apresentadas. Desde já, a diversidade veio a fomentar mais adiante, a necessidade de atrair investimentos à outras regiões menos favorecidas, o que não era implementado na época monárquica, gerando também revoltas internas, conduzindo à derrocada do regime.

O período imperialista brasileiro foi marcado pelo unitarismo e forte centralização política. Essa exagerada concentração de poder nas mãos do Imperador foi cedendo de forma gradual, tanto face às necessidades de empreender um melhor governo, bem como as exigências e revoltas populares clamando por alguma autonomia, que acreditavam inerentes à sua própria formação. Essa asfixia administrativa ameaçava a própria unidade nacional. A Constituição de 1824, já vislumbrando o ideal federalista, buscou corresponder ligeiramente a essa expectativa, sem contudo perder o controle das Províncias, como assim denominou as vinte divisões operadas no território, dirigidas por um Presidente nomeado pelo Governo Central. Nessa época o Presidente da Província (equivalente hoje ao Governador do Estado) era de livre nomeação e remoção, até quando o Imperador decidisse, nos termos constitucionais, que não mais conviria aos bons serviços do Estado. Situação distinta era a das Câmaras Municipais, cujos Vereadores eram eleitos pelo povo diretamente, sendo o seu Presidente aquele com maior número de votos.

No ano de 1834, foi editada a Lei de 12 de agosto de 1834, conhecida como 'A to Adicional', que veio a oferecer ainda mais substrato político para fomentar a luta pelo federalismo. Citado ato cerceou a autonomia municipal, esvaziando sua competência de autogoverno, transformado o Município em um mero executor dos ditames provinciais, ao mesmo passo em que ampliou a competência das Províncias, que passaram a dispor quase da totalidade da gerência dos negócios municipais. Essa mudança de política desagradou os chefes do símbolo da povoação e organização administrativa, ou seja, os 
gestores públicos municipais. No afã de oferecer respostas ao federalistas, D. Pedro II promoveu uma descentralização excessiva e desorganizada, como nos dizeres de Vamireh Chacon "à revelia e em prejuízo das populações vivendo em comunidades reais, os municípios, e não em abstratos Estados" 7 .

O federalismo brasileiro foi inaugurado pelo Decreto . $^{\circ} 1$ de 15 de 11.1889 , em resposta ao regime centralizador adotado pelo monarquia. A principal idéia da federação era conferir aos Estados, antes denominados Províncias, autonomia, bem como incentivar a descentralização no território, de dimensão continental. O impulso federalista foi tão pertinaz que o Decreto ora citado, fruto das paixões políticas, já conferia aos Estados a garantia de exercício de sua legítima "soberania", certamente uma impropriedade da redação, que veio a ser suprimida na primeira Carta Republicana de 24 de fevereiro de 1891. Sem dúvida a adoção do federalismo representa uma das mais importantes contribuições para decidir o problema da descentralização, vindo a ser rapidamente assimilado na política nacional por parecer ideal face às diversidades geográficas, econômicas e sociais existentes à época.

Em 1891, a primeira Constituição republicana, inspirada na Constituição norteamericana estabelecia o federalismo, e presidencialismo como princípios norteadores do regime republicano por um processo jurídico-normativo ${ }^{8} \cdot \mathrm{A}$ Igreja foi desvinculada do Estado e estabeleceram-se eleições diretas para os cargos públicos como Presidente, Governadores, Senadores, Deputados estaduais e federais. Todavia, o ímpeto descentralizador não obteve o êxito esperado, e a centralização a nível Estadual que tomou corpo, fez florescer a 'política dos governadores', ou mais comumente conhecido como 'coronelismo', termo utilizado para definir a dominação e manutenção de famílias no poder. Observava-se a concentração de poder na esfera Estadual, da mesma forma anteriormente existente no período imperial.

Rui Barbosa ${ }^{9}$ já vislumbrava o perigo que rondava o país, quando da implantação do federalismo em um Estado marcado pela desigualdade regional. Seu discurso proferido em 29.01.1891 na Assembléia Constituinte pontificou que

\footnotetext{
${ }^{7}$ VAMIREH, Chacon. "Federalismo aparente e unitarismo permanente no Brasil", RBEP, n. 42, jan. de 1976, pp. 107-126.

${ }^{8}$ HORTA, Raul Machado, "O Estado-membro na Constituição Federal brasileira”. RBEP, n. 69/70, pp. 61-89.

${ }^{9}$ BRASIL. Ministério da Educação e Cultura. "O art. $6{ }^{\circ}$ da Constituição e a intervenção de 1920 na Bahia". In: Obras completas de Rui Barbosa. Rio de Janeiro: Fundação Casa de Rui Barbosa, 1920, vol. XLVII, tomo IV, p. 112.
} 
[...] os Estados grandes disputarão entre si a gestão de negócios públicos, e os Estados pequenos, arrastando uma vida inglória e obscura, não hão de ter a mínima interferência nos negócios de nossa pátria, hão de ser sempre esmagados pela enorme superioridade com que os outros dotam a Constituição do país.

A desigualdade entre os Estados tornou-se gritante. O predomínio de São Paulo e Minas Gerais, que sucessivamente elegiam os Presidentes da República, transformaram-se em verdadeiros redutos eleitorais dominados por 'caciques' políticos interessados em manter a hegemonia política ${ }^{10}$. Esses 'caciques' ou 'coronéis' eram verdadeiros manipuladores, desenvolvendo máquinas eleitorais para fulminar qualquer adversário que se opusesse ao sistema existente, anulando a apresentação de candidatos contrários ao regime.

Para remediar essa situação criada pelas oligarquias frutos de relações econômicas, na verdade de natureza agrária do país, consumou-se, em 1926, a Reforma Constitucional, que veio a restringir a autonomia dos Estadosmembros e alargar a competência da União, medida nitidamente centralizadora.

No ano de 1932 ocorreu a chamada Revolução Constitucional. O então Presidente Getúlio Vargas intervém nos Estados e fulmina a política dos governadores. Verifica-se a vigência mascarada de um Estado Unitário, posto que os Estados-membros estavam sob constante intervenção, ocasionando o desaparecimento da autonomia política e administrativa. Dentre seus feitos pode-se destacar a elaboração do Código Eleitoral, uniformizando as eleições nacionais, liquidando as atribuições que até então eram das Assembléias Estaduais, estabelecimento de garantias e a criação da Justiça Eleitoral responsável para julgar da validade das eleições e nomear e dar posse aos eleitos.

A Constituição de 1934 institucionalizou pela primeira vez, e definitivamente, o federalismo tridimensional brasileiro, estabelecendo a divisão de competência tripartida entre a União, os Estados e os Municípios, estes últimos, relativo a tudo quanto respeitasse ao seu peculiar interesse, para além de discriminar com maior rigor as rendas tributárias entre União, Estados e Municípios, atribuindo a estes autonomia financeira. O Município era autônomo porque

\footnotetext{
${ }^{10}$ Era a chamada política do café com leite, pela analogia dos principais produtos de São
} Paulo e Minas Gerais, respectivamente. 
possuía autogoverno assegurado pela eleição direta de Prefeitos, VicePrefeitos e Vereadores, sendo nomeados, porém, pelo Governador do Estado os Prefeitos das Capitais, das estâncias hidrominerais e dos Municípios decretados como de interesse da segurança nacional. A autonomia abrangia ainda a auto-administração com receitas própria e realização de serviços públicos municipais por funcionários do próprio Concelho.

Houve um acréscimo dos poderes da União, que uniformizou a legislação processual, com prerrogativa de editar, para além dessa matéria, outras relativas direito penal, comercial, civil, aéreo e processual, registros públicos e juntas comerciais; divisão judiciária da União, do Distrito Federal e dos Territórios e organização dos Juízos e Tribunais respectivos; normas fundamentais do direito rural, do regime penitenciário, da arbitragem comercial, da assistência social, da assistência judiciária e das estatísticas de interesse coletivo; desapropriações, requisições civis e militares em tempo de guerra; matéria eleitoral da União, dos Estados e dos Municípios, inclusive alistamento, processo das eleições, apuração, recursos, proclamação dos eleitos e expedição de diplomas, inclusive admissão do voto feminino; comércio interestadual; normas gerais sobre o trabalho, a produção e o consumo; bens do domínio federal, riquezas do subsolo, mineração, metalurgia, águas, energia hidrelétrica, florestas, caça e pesca; organização, instrução, justiça e garantias das forças policiais dos Estados e condições gerais da sua utilização em caso de mobilização ou de guerra.

Até 1934, as competências da União e dos Estados-membros eram radicalmente separadas. Existia à época o federalismo dualista ou clássico, cuja característica principal era a repartição horizontal de competências, cabendo a União e aos Estados parcela delimitada de competências reservadas. No chamado federalismo cooperativo a divisão de competências é de repartição vertical, na qual em uma mesma matéria a União estabelece normais gerais, e os Estados as particularizam de acordo com as especificidades a serem aplicadas no seu território. A separação era tanta, inspirada no modelo norte-americano, que o paralelismo existente entre a União e os Estados era quase que completamente desprovido de relações intergovernamentais. Um exemplo dessa assertiva é traduzido no artigo 5. ${ }^{\circ}$ da Constituição de 1891, verbis: "Art. $5^{\circ}$ - Incumbe a cada Estado prover, a expensas próprias, as necessidades de seu Governo e administração; a União, 
porém, prestará socorros ao Estado que, em caso de calamidade pública, os solicitar". Entre nós, foi a revolução de 1930, e nos Estados Unidos da América do Norte, o New Deal - sobre os reflexos da crise de outubro de 1929 - o estopim que provocou o federalismo orgânico, ou cooperativo.

Na tentativa de atenuar o esvaziamento de competências dos Estados, surgiu a competência residual, na qual podiam legislar de forma supletiva ou complementária sobre diversas matérias de competência precípua da União.

A vigência da Constituição de 1934 foi muito curta, somente três anos depois, em 1937, vigorava outra Carta Política que fortaleceu ainda mais os poderes da União e dos Municípios. A Constituição dos Estados Unidos do Brasil, como acostado no texto, foi fruto de um golpe do mesmo Getúlio Vargas, que após dissolver o Congresso Nacional implantou o denominado Estado Novo, prometendo plebiscito para aprová-lo, ato que nunca aconteceu. Estava estabelecida a ditadura em resposta aos reclames comunistas operados ainda no pós-guerra de 1918, cujas idéias foram trazidas da Europa, especialmente pela Alemanha e Itália face os regimes totalitaristas, sob falsa alegação de subversão da ordem pública. O Presidente da República concentrava o Poder Legislativo e Executivo, por via de decretos-lei que ele mesmo aplicava.

Ainda que a Constituição de 1937 afirmasse ser o Brasil um Estado federal, constituído pela união indissolúvel dos Estados, do Distrito Federal e ainda dos Territórios, o que estava na prática era a contínua intervenção federal no Estado para restabelecer a ordem gravemente alterada, ou qualquer outra alegação que pudesse adaptar-se com as hipóteses constitucionais vigentes. Os Estados não passavam formalmente de meras descentralizações territoriais, sendo regidos pelo Decreto-Lei n. ${ }^{0} 1.202$, de 08 de abril de 1939, erigido a uma espécie de 'lei orgânica' dos entes federados, indo de encontro à autonomia inerente que se deve conferir a um integrante da federação.

Até o advento da próxima Constituição, que deu-se em 1946, as atenções voltaram-se principalmente para a deflagração da Segunda Grande Guerra, o que permitia uma margem ampla para administrar o regime longe dos olhos populares. No entanto, após o término da Guerra, e a ruína de um totalitarismo o qual o Brasil ofereceu tropas para combater, era uma contradição manter o 
regime ditatorial. A capitulação ocorreu em 1945, com a deposição do Presidente Getúlio Vargas, substituído por José Linhares, então Presidente do Supremo Tribunal Federal. Era o fim do Estado Novo.

Pode-se dizer que a Constituição promulgada em 18 de setembro de 1946 restabeleceu a Federação no seu sentido real. Inspirada em ideais norteamericanos (mantinha o título de Constituição dos Estados Unidos do Brasil), franceses e alemães, foi tida como uma das mais importantes, porque buscava a harmonização entre a classe proletária que insistia na participação, e a burguesa conservadora. No entanto, no que tange à federalização, os avanços foram ínfimos. A hipertrofia do Poder Central alcançada no período anterior fazia-se ainda muito presente, haja vista nada menos do que serem treze as hipóteses definidas como capazes de deflagrar a intervenção da União nos Estados, dentre elas, ressalte-se, a não observância por parte do Estadomembro do princípio da autonomia municipal, ao passo que as possibilidades de reduzir a autonomia municipal por intervenção cingia-se apenas a dois casos, ambos regularizadores de finanças.

Emenda Constitucional n. ${ }^{\circ}$ 5, de 21 de novembro de 1961, veio a atrair mais atenções aos Município, quando no próprio texto constitucional já existia, pela primeira vez, a vinculação de receita oriunda da arrecadação federal a ser repartida entre Estados e Municípios, este último, pela Emenda, aumentou seu percentual de $10 \%$, para $15 \%$ da arrecadação do imposto sobre a renda, atribuindo-lhe ainda mais $10 \%$ do total arrecadado com o imposto sobre o consumo.

Os militares insatisfeitos com a política populista adotada e o descontrole econômico que gerou inflação desenfreada em 1964, resolveram assumir o poder. Escudados no argumento de reestruturação do governo e desenvolvimento, promoveram o fortalecimento do Poder Executivo tomando à força o poder das mãos do Presidente João Goulart, à época vice de Jânio Quadros, que havia renunciado. Falava-se em preocupação com a eficiência, racionalidade e moralidade do processo político-administrativo, enfatizando a responsabilidade do agente público. O início da ditadura militar deflagrou uma infinidade de intervenções estaduais, bem como toda sorte de Atos institucionais para adaptar a Constituição, à vontade do Executivo (como ainda hoje se observa através das Emendas Constitucionais). 
Para a ruína do sistema federativo, os sucessivos ditadores militares necessitavam cada vez mais centralizar o Poder para estar sempre no domínio da situação. A autonomia dos Estados e dos Municípios foi notavelmente reduzida face as perseguições políticas que arbitrariamente ensejavam o emprego da intervenção. Os acontecimentos em cadeia gerados pelo abuso de Poder, o centralismo exacerbado necessitava para a sua mantença cada vez mais recursos, o que por sua vez levou a diminuição da competência tributária dos Estados e dos Municípios.

Após vinte emendas constitucionais e três atos institucionais e aproximadamente quarenta atos complementares, a Constituição de 1946 deu lugar a de 1967, promulgada em 24 de janeiro, omitindo pela primeira do texto constitucional a referência aos 'Estados Unidos do Brasil', para simplesmente denominar Constituição do Brasil, sendo este uma República Federativa, constituída sob o regime representativo, pela união indissolúvel dos Estados, do Distrito Federal e dos Territórios.

A arbitrariedade imperava. O federalismo ruía ante a impotência do judiciário e a legalidade estava suspensa para aqueles que insistiam em combater o atual governo. Qualquer simpatizante ou seguidor do antigo regime era considerado revolucionário, subversivo, dando margem à prisão política.

Alheias às medidas tomadas no lapso constitucional anterior, a crise política $\mathrm{e}$ econômica seguia a passos largos e a última manobra se concretizou pelo Ato Institucional n. ${ }^{\circ} 5$ de 13.12.68, considerado como o maior instrumento de centralização, conferindo ao Presidente poderes quase que ilimitados. Da fonte inspiradora do federalismo brasileiro, a Federação norte-americana, não se vislumbrava quase que mais nenhuma semelhança.

A EC n. ${ }^{\circ} 1$ promulgada pelos Ministros da Marinha de Guerra, do Exército e da Aeronáutica Militar à data de 17 de outubro de 1969, face às modificações introduzidas na Constituição de 1967, é denominada por alguns publicistas de Constituição de 1969, posto que até mesmo a sua denominação foi alterada, passando a ser Constituição da República Federativa do Brasil. Assim, embora formalmente a emenda alterasse o texto anterior, tratava-se, em verdade, de uma nova Carta. 
Observando a evolução história constitucional brasileira, temos que desde 1891, nossas constituições sempre foram alargando cada vez mais o espaço no âmbito do poder do Executivo, construindo uma supervalorização da União na pessoa do Presidente da República, em detrimento a um cerceamento autonomia reservada aos Estados Federados.

O fim do regime militar foi marcado pela Constituição de 1988, denominada 'cidadã', 'democrática'. Na tentativa de afastar-se dos moldes centralistas das anteriores, conferiu mais recursos, especialmente no âmbito tributário, aos Estados e Municípios, posto que sem numerário para fazer valer o autogoverno, falece a autonomia. A maior relevância a nível políticoadministrativo organizacional trazido pela CF de 1988, foi o fato de erigir o Município, ao lado dos Estados e da União Federal, a qualidade de ente da Federação.

Observada por uma óptica geométrica, a União está ao lado dos Estados e Municípios, cuja diferença está delineada no texto constitucional, especificamente no que tange a competência de cada. No modelo federativo brasileiro convivem quarto pessoas de Direito público, a saber: União, Distrito Federal, Estados-membros e Municípios, todos autônomos. Cada qual desses entes possui sua casa legislativa, e por isso a Constituição estabeleceu limites à competência legislativa individual. Destarte, à União cabem os poderes privativos, expressamente definidos no art. 22, concorrentes aos Estados e Distrito federal, os gravados no art. 24. Aos municípios compete legislar de forma supletiva à federal e estadual no que couber, e privativamente no que tange à instituição e arrecadação de tributos ${ }^{11}$ inerentes ao seu tesouro e de forma genérica, dispor em tudo que restar demonstrado o interesse local. Aos Estados-membros é entregue a competência de tratar dos demais assuntos a ele não vedados, ou seja, poderes remanescentes ou residuais.

\footnotetext{
${ }^{11}$ A Constituição brasileira distingue três espécies de tributos: impostos, taxas e contribuições de melhoria. Os impostos, sempre que possível, terão caráter pessoal, respeitando o princípio da capacidade contributiva e da vedação ao confisco. As taxas serão instituídas em razão do exercício do poder de polícia, ou pelo uso, efetivo ou potencial de serviços públicos específicos e divisíveis, prestados ou postos à disposição do contribuinte. As contribuições de melhorias serão devidas, após realização de obras públicas que produzam efetiva melhora de qualidade de vida, valorização predial.
} 
Do ponto de vista constitucional, pode-se afirmar que a autonomia federal está razoavelmente bem distribuída entre os entes federativos, cujas garantias permitem a viabilização do pacto federativo. Juntamente com a União Federal, aos Estados-membros e o Distrito Federal foi assegurada a competência concorrente; os Municípios, além da competência privativa e a de interesse local, divide juntamente com os demais entes da federação, a competência comum (CF, art. 23).

No campo tributário e financeiro, a União Federal, os Estados-membros, Distrito Federal e Municípios exercem amplamente sua competência, com independência e sem interferências, o que é um reforço da autonomia política, posto que as ações de arrecadação dos recursos é própria de cada ente da federação e aplicação de rendas é realizada com ampla liberdade, dentro da lei, com contas a prestar somente junto ao Tribunal de Contas.

\section{[1- O Municí́lo brasileiro e o pacto federativo}

O Estado brasileiro consagrou em sua Constituição de 1988 que a República Federativa é composta pela união indissolúvel dos Estados, Municípios e do Distrito Federal (art. 1. ${ }^{\circ}$ ), não sendo possível qualquer tentativa de modificar a forma federativa de Estado, por força do art. $60, \S 4^{\text {ol2 }}$.

Faz-se necessário explicitar que por motivos históricos, bem como por pressão dos defensores mais ferrenhos do municipalismo, o constituinte achou por bem incluir, de forma singular, os Municípios na forma federativa de organização política do Estado.

Evocando raízes históricas e geográficas, somos levados a concluir que devido à extensão territorial, sempre foi difícil governar o Brasil. A imensidão do território dificultava a centralização política, e a distância do Reino de Portugal, aliada as dificuldades de comunicação favoreceram o crescimento individual e quase que isolado das municipalidades. Com base nesse conceito, o Município era forçado a resolver as suas próprias dificuldades, a solucionar seus problemas, convergindo as lideranças locais no sentido de que a autonomia deveria ser algo consagrado e preservado. Essa lonjura entre Lisboa e os municípios brasileiros contribuiu em muito para que estes

\footnotetext{
12 “ $\$ 4^{\circ}$ - Não será objeto de deliberação a proposta de emenda tendente a abolir: I - a
} forma federativa de Estado;" 
desfrutassem de um poder considerável. Imaginemos pois como seria submeter qualquer iniciativa popular ao Reino, esperar por sua análise e posterior resposta, quanto tempo tardaria todo esse trâmite e traslado? No entanto, para dissipar qualquer atitude contrária a Coroa, para debelar e ao mesmo tempo evitar levantes capazes de fomentar a independência, tal autonomia não era a princípio apoiada, não se podia perder o controle dos aglomerados populacionais.

Adiante, após a independência em 07 de setembro de 1822, as constituições foram gradualmente consagrando o princípio da autonomia dos governos locais. Iniciada discretamente pela Constituição do Império (1824), que conferiu "ao Governo local especial relevo, através de uma verdadeira experiência de governo autônomo, à semelhança do que se praticava alhures, entre povos mais evolvidos e civilizados"13, a autonomia municipal sempre foi ponto controvertido, mesmo porque poucos aqueles que possuíam recursos suficientes para se auto-administrar (selfgovernment). Assim, apesar de consagrada a autonomia político-administrativa, a mesma não passava de mera denominação, devido à penúria financeira experimentada pelos Municípios, sempre dependentes da ajuda externa ${ }^{14}$.

A penúltima constituição brasileira (de 1967, alterada pela Emenda Constitucional n. 01 de 1969, cujo preâmbulo diz “o Brasil é uma República federativa, constituída pela União indissolúvel dos Estados, do Distrito Federal e dos Territórios)" foi elaborada nos moldes impostos da ditadura militar, e mesmo conferindo eleições diretas para os Municípios (e somente para estes) - e assim mesmo não a todos, posto que os considerados de segurança nacional (por lei de iniciativa do Poder Executivo Federal), os de estâncias hidrominerais (assim considerados por lei estadual) e as capitais dos Estados ${ }^{15}$, os chefes do Executivo eram escolhidos pelo Governador - delegaram inúmeras atribuições aos Municípios.

${ }^{13}$ PAUPÉRIO, A. Machado. O Município e seu regime jurídico no Brasil. $2^{a}$ ed., Rio de Janeiro: Forense, 1973, p. 40.

${ }^{14}$ Cfr. Adílson Abreu Dallari, "Autonomia municipal na Constituição Federal de 1988”, RDP, a. 24, n. 97, jan./mar. de 1991, SP, pp. 231-238.

${ }^{15}$ No primeiro caso carecia de prévia aprovação do Presidente da República, nos dois últimos, a nomeação dependia de prévia aprovação da Assembléia Legislativa.

A Constituição de 1946 permitia ao Governador nomear os prefeitos das capitais e das estâncias hidrominerais e os municípios considerados de segurança nacional, independentemente do aval da Assembléia ou do Presidente da República, conquanto a de 1937 limitou-se à redação de que "O prefeito será de livre nomeação do Governador do Estado". 
No entanto, sabido é que para a fiel consecução dessas atribuições, é preciso a existência de recursos financeiros, que os Municípios não dispunham. Assim, ficavam sempre compelidos a solicitar (leia-se mendigar ou trocar por outros favores políticos) verbas ao Estado ao que estava circunscrito, ou diretamente ao Ministério relacionado à obra ou serviço que fosse realizar. Como bem questiona Dallari ${ }^{16}$, se o Município iria dispor de determinada verba para aplicar em obras de interesse local, por qual razão a quantia não ingressa diretamente seus cofres? Fortaleceria, sem dúvida, ainda mais a autonomia se assim fosse. Agindo dessa forma, o Governo Federal bem como Estadual, poderia exercer um controle não apenas dos atos dos prefeitos, bem como influir politicamente, comprometendo a administração pública e/ou favorecendo a quem lhe aprouvesse.

A Carta Política de 1988 amenizou essa situação, dessa vez conferindo real autonomia financeira aos Municípios. Atualmente, detentores ainda mais de fontes de renda próprias, os Municípios vêem creditar diretamente em suas contas, parcelas referentes a outros tributos, sejam provenientes da arrecadação estadual ou federal, sem o descaminho que outrora ocorrera, ou seja, as quotas ingressavam primeiro noutro patrimônio (estadual ou federal), para daí então serem transferidas, durante todo esse percurso, muitas cifras perdiam-se ao longo do caminho.

Além dessa inovação, a Constituição de 1988 modificou a anterior no que tange a Lei Orgânica Municipal. Outrora, cabia ao Estado disciplinar sobre a Lei Orgânica dos Municípios, fazendo com que um único modelo servisse para todos, obedecendo a uma legislação estadual uniformizada. Doravante, cada Município elabora sua Lei Orgânica ${ }^{17}$, devendo apenas obedecer a parâmetros definidos pela própria Constituição Federal e Estadual (CF art. 29), e, por fim, adicionou o Município como ente integrante da Federação.

Contudo, apesar dessa evolução autonômica do Município brasileiro, não se pode considerar que estes pressuponham uma entidade federada. Aliás, este

\footnotetext{
${ }^{16}$ Ibidem, p. 231.

${ }^{17}$ Hoje os municípios podem se organizar de forma a estabelecer a melhor maneira de prestar seus serviços, se aproximando da realidade de sua comunidade. Ora, parte-se da premissa de que cada localidade possui peculiaridades próprias, com carências e riquezas. Não se concebe uma uniformidade demográfica, social e econômica em áreas tão vastas e diversificadas.
} 
sempre se manteve à margem da composição dos entes federativos, desde a Constituição de 1891 , seguida pela de $1934^{18}$, 1937,1946 e por fim na de $1967^{19}$.

O Estado Federal é composto por uma associação de Estados, que poderá decorrer de aglutinação histórica, quando Estados preexistentes dão origem ao Estado Federal, bem como por imputação normativa, através de criação jurídica dos Estados, no documento de fundação do Estado Federado. No caso brasileiro, vislumbra-se o segundo, em que as Províncias foram denominadas Estados e a Constituição os aglutinou na forma federativa, gerando concomitante o nascimento jurídico do Estado Federal e dos Estados-membros, que passaram a integrar a República Federativa. Mas será que a Constituição atual, ao incluir o Município como ente da Federação, não contradiz o princípio federativo? Afinal, este não é ente constitutivo da Federação, principalmente da brasileira, posto que a evolução constitucional sugere que esta seja oriunda da composição das Províncias, transformadas em Estados.

Desde 1934 que as Constituições mencionam que os Territórios compõem a República Federal, um exagero, segundo Raul Machado Horta, sustentando que estes "são desdobramentos da atividade administrativa da União, configurando a autarquia territorial, por descentralização de objetivos da União Federal, na qual eles se integram em relação de dependência e de subordinação"20 . Todavia, a Constituição de 1988 excluiu os Territórios da organização da República, integrando-os na União, e por sua vez forçosamente incluiu os Municípios, pessoas de direito público interno, como partícipe da República Federativa. Essa inclusão é combatida pelo mesmo autor, ao afirmar que a

${ }^{18}$ Constituição esta que esboçou autonomia municipal como sendo o conteúdo de três elementos: autonomia política, financeira-tributária e autonomia administrativa, e ainda inseriu o município em Título específico que trata da Organização Federal. Daí por diante, o Município passa formalmente a fazer parte da União.

${ }^{19}$ Cfr. Raul Machado Horta, em “A posição do município brasileiro”. RBEP, n. 55, julho 1982, pp. 197-221, "O desdobramento lógico da concepção constitucional que desconhecia o município no plano da União Federal ou da Federação - por ser a União, historicamente, como no caso brasileiro, a resultante da aglutinação de Províncias que se tornaram Estados-membros -, deveria conduzir à exclusão do Município do domínio da Constituição Federal”.

${ }^{20}$ In: "O Estado-membro na Constituição Federal brasileira". RBEP, n. 69/70, jul. 1989 jan. 1990, p. 61. 
[...] relevância do Município na Constituição Federal [...] dispensa, e não justifica, a presença do Município na composição do Estado Federal, produto da associação dos Estados Federados, como vimos, dentro da natureza ontológica e jurídica dessa forma de Estado, qualificada, por isso, de União de Estados de Direito Interno", para adiante afirmar que o tratamento dado pelo poder constituinte originário é altamente sujeito a reprovações, dado a falta de atenção ao não identificar a "União Federal como ordenamento central do Estado Federal ou da República Federativa. A União permanece oculta na cláusula da união indissolúvel, que vincula os ordenamentos parciais dos Estados e do Distrito Federal, sem explicitar a presença da União Federal na composição da forma de Estado.

Como bem afirma Baracho ${ }^{21}$, os únicos entes federativos são o Estado Federado e os Estados-membros, excluídos os Municípios. Estes não fazem parte da Federação, e sim Estados a perfazem. Uma das justificativas, para além do próprio valor axiológico que o termo nos remete, é de que

[...] os Municípios não influem, nem muito menos decidem, no Estado Federal. Dito de outro modo, não participam da formação da vontade jurídica nacional. Realmente, não integram o Congresso, já que não possuem representantes nem no Senado (Casa dos Estados), nem na Câmara dos Deputados (Casa do Povo). Como isso não bastasse, a autonomia não é uma cláusula pétrea. O Congresso Nacional, no exercício de seu poder constituinte derivado, pode querendo, aprovar emenda constitucional que venha a diminuir ou mesmo, a eliminar a autonomia dos Municípios ${ }^{22}$.

Só existem quatro hipóteses em que não é possível a proposta de emenda constitucional: as tendentes a abolir (leia-se abolir, e não modificar, o que poderia ensejar a exclusão do Município no pacto federativo) a forma federativa de Estado; o voto direto, secreto, universal e periódico; a separação dos Poderes; os direitos e garantias individuais. Para além dessa exemplificação toda e qualquer proposta deve ser levada a plenário, basta examinar a Proposta de Emenda Constitucional (oferecida pelo Governo - Poder Executivo) n. ${ }^{\circ}$ 297, de 1995.

${ }^{21}$ BARACHO, José Alfredo de Oliveira. Teoria geral do federalismo. Rio de Janeiro: Forense, 1986, p. 204.

${ }^{22}$ CARRAZA, Roque Antônio. Curso de Direito Constitucional Tributário, 12 ed., São Paulo, Malheiros, 1999, p. 106. 
Outro aspecto relevante merecer ser ventilado quando se defende que o Município não faz parte da federação, trata-se dos titulares dos direitos de propor Emendas à Constituição. A Constituição brasileira admite que poderá sofrer emendas sob proposta: de no mínimo um terço dos membros da Câmara dos Deputados ou do Senado Federal; do Presidente da República; por mais da metade das Assembléias Legislativas das unidades da federação, manifestando-se, cada uma delas, pela maioria relativa de seus membros. É o que diz o art. 60 , incisos I a III.

No esteio do pensamento de Roque Carraza, bem como nos dizeres da Lei Complementar n. ${ }^{\circ}$ 78, de 30 de dezembro de 1993, a Câmara de Deputados é composta proporcionalmente pela densidade demográfica dos Estados, e não pelo seu número de Municípios ou população Municipal. Por sua vez, o Senado Federal é composto por representantes de interesses do Estado e do Distrito Federal, cuja eleição segue o princípio majoritário. À luz da primeira hipótese temos que o Poder Legislativo de representatividade nacional é o maior interessado em modificar a Constituição.

O Presidente da República, chefe de Estado, representante máximo do Poder Executivo é igualmente hábil para propor Emendas à Constituição. Simboliza o interesse nacional como um todo, abstraindo-se o localismo.

A derradeira hipótese de modificar o texto máximo é ao nosso ver a mais complexa a nível de concretização. Exige-se maioria relativa de catorze Assembléias Legislativas dos vinte e sete Estados da federação, significa dizer $50 \%$ mais um destes. Somente um fator de relevância desmedida, e esgotadas as proposituras que porventura a Câmara dos Deputados e o Senado Federal pudessem apresentar, levaria a uma maioria de casas legislativas, de diversos pontos do país, a adotar uma posição uníssona no sentido de modificar a Lei Magna. A possibilidade, ainda que remota, sinala a grande valia dos Estados-membros.

Se o Município fosse ente integrante do pacto federativo, deveria estar entre o rol dos possíveis autores de apresentar propostas de emenda à Constituição. Se não um único Município, pelo menos um conjunto mínimo com representatividade suficiente e expressiva para esse desiderato, como por exemplo associação de Município ${ }^{23}$.

\footnotetext{
${ }^{23}$ Defendemos o associativismo pela sua natureza em que o fim perseguido seja genérico e comum aos Municípios associados, ao passo que o consórcio seria efêmero, cuja duração se prolongaria tão somente enquanto se realizasse a obra ou serviço determinado.
} 
Com bem apontado pelo prof. Baracho, vale ainda acrescentar que os Municípios não possuem representação direta no Senado Federal, ao revés dos Estados-membros, que elege seus Senadores, não tem competência para propor emendas constitucionais, não possuem Poder Judiciária próprio (os Estados e a União Federal possuem no âmbito de sua competência) e, o chefe do executivo municipal não pode propor ação de inconstitucionalidade. É a própria Constituição em seu artigo 45 que afirma ser a Câmara dos Deputados composta de "representantes do povo, eleitos pelo sistema proporcional, em cada Estado, em cada Território e no Distrito Federal", e no artigo 46 registra que "o Senado Federal compõe-se de representantes dos Estados e do Distrito Federal". Até mesmo na formação contínua e aperfeiçoamento do servidor público, é o Município excluído de tal tarefa, posto que somente a União, os Estados e o Distrito Federal são obrigados a prover escolas para esse fim específico $\left(\mathrm{CF}\right.$, art. $\left.39, \S 2^{\circ}\right)$. Vale mencionar também que enquanto os Deputados Estaduais possuem imunidade formal e material, os Vereadores dispõem apenas da material - opiniões, palavras e votos - (CF, art. 27 e 29, VIII). Por fim, se ente federado é, porque não possui constituição como os Estados, ao invés de Lei Orgânica?

Arrebatando tal questão, José Afonso da Silva ${ }^{24}$ defende que não somente pela autonomia política-constitucional que possui uma coletividade territorial, significa dizer "que necessariamente integre o conceito de entidade federativa. Nem o Município é essencial ao conceito de federação brasileira”. E assim o justifica, tanto pela responsabilidade conferida à legislação Estadual, de criar,

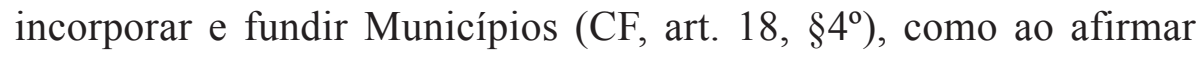
irreparavelmente que ?????????????????

[...] a República Federativa do Brasil é formada de união indissolúvel dos Municípios é algo sem sentido, porque se assim fora, ter-se-ia que admitir que a Constituição está provendo contra uma hipotética secessão municipal. Acontece que a sanção correspondente a tal hipótese é a intervenção federal que não existem em relação aos Municípios situados nos Estados. A intervenção neles é da competência destes, o que mostra serem ainda vinculados a eles". A Constituição do Brasil não vislumbra a hipótese de intervenção federal nos Municípios localizados nos Estados $^{25}$.

${ }^{24}$ SILVA, José Afonso da. Curso de direito constitucional positivo. $13^{\mathrm{a}}$ ed., São Paulo: Malheiros, 2000, pp. 450-451.

${ }^{25}$ Neste mesmo sentido vai o parecer não publicado de Brasilino Pereira dos Santos, acostado aos autos do mandado de segurança . $^{\circ}$ 1998.34.00.005102-3, cujo impetrante é o Município de Campo Grande e outros, em desfavor do Secretário do Tesouro Nacional. 
De forma a garantir exaustivamente a tão disputada autonomia de governo, a administração e legislação própria no âmbito de suas competências, bem como os recursos financeiros próprios, aliado ao fato de que os Municípios a cada dia são forçados a solucionar as carências da população local, o Constituinte, atento ao frágil apego nacional ao cumprimento de Lei, forçou o processo de constitucionalização de quase todas as matérias. Para se evitar uma pulverização de modelos de Municípios (e será que isso não favoreceria a autonomia?), foram fixados diversos limites. Verifica-se que a Constituição trata exaustivamente de matéria que não possui a real necessidade de ali estar, como por exemplo, fixar o número de Vereadores, a data das eleições municipais, duração do mandato (CF, art. 29), assuntos que poderiam perfeitamente estar agasalhados em sede de legislação infra-constitucional.

Para resguardar a autonomia municipal não se faz necessária a pormenorização de todas as competências e atribuições das coletividades locais, mesmo porque na própria Constituição existe mecanismo para protegê-la, qual seja, a Intervenção Federal (art. 34, VII, c).

A par dessas exemplificações, torna-se difícil sustentar a posição do Município brasileiro com parte integrante do pacto federativo. Bem verdade é que lá está positivado, formalmente, mas em teoria, trata-se de uma imperfeição anotada pelo poder constituinte originário. Adota-se muita vezes o conformismo, como estampado nas palavras da professora Cristiane Mendonça ${ }^{26,}$ verbis:

No caso da República Federativa do Brasil, deve ser acrescido o ente municipal, que a despeito de não ser parte da federação em sentido estrito, conforma o Estado Brasileiro, é dotado de autonomia e está em posição de paridade em relação aos Estados e à União, e ainda, o Distrito Federal, que ao lado das demais pessoas políticas compreende a união indissolúvel, preconizada no $\operatorname{art.} 1^{\circ}$., caput, da $\mathrm{CRFB} / 88$.

Como bem dito:

[...] ao configurar-se no plano da federação brasileira, com todas as peculiaridades que o circunscrevem, o Município brasileiro posiciona-se em patamares ímpares aos demais Municípios de todas as outras federações do

\footnotetext{
26 "A Imunidade tributária entre as pessoas políticas de direito público interno". In: Novos Rumos da Autonomia Municipal. Coordenador: Evandro de Castro Bastos e Odilon Borges Júnior. São Paulo: Max Limonad, 2000, pp. 81-89.
} 
mundo. Mas seu realce, no concerto da Federação, não lhe outorga, em nosso ordenamento constitucional, a peça de ente federativo, como equivocadamente se sustenta alhures, apaixonadamente. ${ }^{27}$

Consoante esse conjunto de argumentos, acreditamos que os Municípios efetivamente não fazem parte do pacto federativo, ainda que formalmente, assim esteja positivado. Para alcançar verdadeiramente esse desiderato, é necessário fazer adaptações ao texto constitucional, especialmente no que tange à representatividade no Congresso Nacional, e a cláusula pétrea de plena autonomia municipal.

\section{Conclusão}

O Município brasileiro foi concebido inicialmente nos moldes dos Concelhos portugueses. No entanto, a vastidão do território, aliada às diversas condições econômicas, sociais e políticas que se deflagraram na colônia, fizeram com que ganhasse gradativa autonomia. A autonomia municipal foi sendo construída ao sabor dos anos e de acordo com a necessidade de conferir aos entes locais, capacidade resolutiva de seus problemas, sem necessitar, a princípio, a participação das unidades políticas maiores. No entanto essa prerrogativa foi bastante dificultada nos anos de unitarismo, e quando da prática da política dos governadores que insistiam em fazer dos Municípios um reduto político eleitoral dominado por uma família predominante, ou, pela disputa entre duas ou mais, do poder local.

A Constituição de 1988 alçou os Municípios brasileiros à invejável condição de pessoa política integrante da federação, uma inovação única conhecida no mundo jurídico. Aautenticidade da autonomia conferida a este ente da federação é indiscutível, e sua formação no decorrer de toda evolução constitucional e administrativa brasileira, ocorreu de maneira com espontaneidade singular, em contraposição ao caráter abrupto e artificial com que se foi implantado o Estado Federal em 1891. A autonomia municipal entre nós, o fortalecimento do pode local, mesmo do ângulo estritamente jurídico-formal, já finca raízes relativamente profundas no nosso constitucionalismo.

A autonomia política, administrativa e financeira experimentada pelos Municípios, é oriunda da própria Constituição Federal. Essa autonomia é confirmada pela eleição direta dos representantes, que podem elaborar a Lei

${ }^{27}$ Cfr. CASTRO, José Nilo de. Direito municipal positivo. $4^{\mathrm{a}}$ ed., Belo Horizonte: Del Rey, 1998, p. 60. 
Orgânica Municipal, legislar sobre os assuntos de interesse local, organizar e prestar os serviços a serem oferecidos à população, bem como instituir os tributos e aplicar a receita oriunda destes, identificados na Lei Maior.

A liberdade e a autonomia municipais são condições indispensáveis para a efetivação do processo democrático descentralizado. A autonomia legislativa do Município é restrita aos assuntos de seu predominante interesse, localizado no âmbito de sua área territorial, o que não significa, todavia, a exclusão da União federal e dos Estados-membros como igualmente interessados na matéria a ser versada pela municipalidade, como se observa da distribuição de competências oferecidas pela Carta de 1988.

Cada Município possui seus tributos próprios, além de aferir receitas de outros entes de direito público. De certo que por vezes os recursos são insuficientes para a totalidade de despesas efetivadas. O que se extrai desse cenário é que não se trata apenas de uma crise política ou financeira, mas quase em sua totalidade, administrativa. Falta no Brasil uma escola de dirigentes públicos, onde profissionais e populares sejam lapidados para exercerem cargos públicos, ao revés de aventureiros lançarem-se a administrar a coisa pública. Há de se buscar um aperfeiçoamento ao lidar com o erário do povo e com isso evitar que os sucessores nas administrações municipais sirvam apenas para pagar o legado da gestão anterior.

Apesar de duvidarmos da posição do Município como ente da federação, há de se concordar que a atribuição de competências expressas positivadas no texto constitucional, aliada à eleição dos governantes, bem como o estabelecimento do remédio jurídico para estabilizar a harmonia do Estado federado nos casos que especifica, robustece a posição de integrante do pacto federativo. Certamente a ausência de representatividade no Congresso Nacional é uma falha grave que carece de reparo, mas de difícil resolução, haja vista a existência de 5.561 28 unicípios espalhados pelos 27 Estadosmembros, alia-se a essa observação, a inexistência do Poder Judiciário próprio do citado ente federado e a ínfima quantidade de Municípios que se auto sustentam, abalando as raias da autonomia, bem como a impossibilidade destes entes não poderem apresentar proposta de Emenda à Constituição, tampouco poderem ingressar com Ação de Inconstitucionalidade junto ao Supremo Tribunal Federal.

\footnotetext{
${ }^{28}$ Dados do IBGE no apurados no último censo, realizado em 2000.
} 


\section{Bibliografia}

AGUIAR, Joaquim Castro. Competência e autonomia dos municípios na nova Constituição. Rio de Janeiro: Forense, 1995.

BARACHO, José Alfredo de Oliveira. "Novos rumos do federalismo", RDP, a. VXI, n. 65, jan./mar. de 1983, pp. 5-26.

. Teoria geral do federalismo. Rio de Janeiro: Forense, 1986.

. "Descentralização do poder: federação e município.”, RDP, a. III, n. 5 e 6 , jan./jun. e jul./dez. de 1989, pp. 11-40 e 11-28.

BARROSO, Luís Roberto. Direito constitucional brasileiro: o problema da federação. Rio de Janeiro: Forense, 1982.

BONAVIDES, Paulo. "Do velho ao nôvo federalismo", RDA, vol. 70, out./ dez de 1962, pp. 500-515.

BRASIL. Ministério da Educação e Cultura. "O art. $6 .^{\circ}$ da Constituição e a intervenção de 1920 na Bahia”. In: Obras completas de Rui Barbosa. Rio de Janeiro: Fundação Casa de Rui Barbosa, 1920, vol. XLVII, tomo IV.

BRASILEIRO, Ana Maria. O município como sistema político. Rio de Janeiro: Fundação Getúlio Vargas, 1973.

BRAZ, Petrônio. "Município: ente federativo", RT, a. II, n. 8, jul./set. de 1994, pp. 103-107.

BRÜHL, Dieter. “A constituição de 1988 e os municípios brasileiros”. Revista de Informação Legislativa, a. XXX, n. 118, abr./jun. de 1993, pp. 41-52.

CARRAZA, Roque Antônio. Curso de direito constitucional tributário. $12^{a}$ ed., São Paulo: Malheiros, 1999.

CASTRO, José Nilo de Castro. Morte ou ressurreição dos municípios? Rio de Janeiro: Forense, 1985.

. Direito municipal positivo. 4ª ed., Belo Horizonte: Del Rey, 1998.

CAUPERS, João. A administração periférica do Estado. Lisboa: Aequitas, 1994. 
DALLARI, Adílson Abreu. "Autonomia municipal na Constituição Federal de 1988”, RDP, a. 24, n. 97, jan./mar. de 1991, SP, pp. 231-238.

FERREIRA, Luiz Pinto. Princípios gerais do direito constitucional moderno. Vol. II, 6a ed., São Paulo: Saraiva, 1983.

FRANCO SOBRINHO, Manoel de Oliveira. "Município e descentralização". Jurídica, a. XII, vol. XXXI, n. 94, jul./set. de 1966, pp. 456-462.

GARCÍA-PELAYO, Manuel. Derecho constitucional comparado. Madrid: Alianza, 1993.

HORTA, Raul Machado. “A posição do município brasileiro”. RBEP, n. 55, julho 1982, pp. 197-221.

. "O Estado-membro na Constituição Federal brasileira", RBEP, n. 69/70, jul./1989-jan./1990, pp. 61-89.

JELINNEK, Georg. Teoria general del estado. Traducción: Fernando de los Rios, Buenos Aires. Albatros, 1954.

KELSEN, Hans. Teoria pura do direito. Trad. João Baptista Machado. $6^{a}$ ed., São Paulo. Martins Fontes, 1998.

KRELL, Andreas Joachim. "Diferenças do conceito, desenvolvimento e conteúdo da autonomia municipal na Alemanha e no Brasil". Revista de Informação Legislativa, vol. 32, n. 128, out./dez. 1995, pp.107-125.

LEAL, Victor Nunes. Alguns problemas municipais em face da Constituição. Problemas de Direito Público. Brasília: Ministério da Justiça, 1999, v. 1, pp. 312-337.

LUCAS VERDÚ, Pablo. Curso de derecho político. Vol. II, Madrid. Tecnos, 1986.

MACHADO JÚNIOR, J. Teixeira. "Regionalização ou municipalização do Brasil?”, RBEP, n. 63/64, jul./1986 - jan./1987, pp. 171-183.

MARINHO, Josaphat. “Intervenção em município", RDP, n. 64, out./dez. de 1982, pp. 60-74.

MEIRELLES, Hely Lopes. Direito municipal brasileiro. 11ª ed., São Paulo. Malheiros, 2000. 
MELLO, Celso Antônio Bandeira de. Natureza e regime jurídico das autarquias. São Paulo. Editora Revista dos Tribunais, 1968.

. "O governo municipal brasileiro: uma visão comparativa com outros países”, RAP, a. 27, vol. 4, out./dez. de 1993, pp. 36-53.

MENDONÇA, Cristiane. A Imunidade tributária entre as pessoas políticas de direito público interno. In: BASTOS, Evandro de Castro; BORGES JÚNIOR, Odilon. Novos Rumos da Autonomia Municipal. São Paulo: Max Limonad, 2000, pp. 81-89.

NABAIS, Casalta. “Autonomia local”. BFD, número especial, 1993, pp. 107-221.

NOGUEIRA, Ataliba. “Teoria do Município". RDP, Editora Revista dos Tribunais, a. 2, n. 6, out./dez. de 1968, pp. 7-21.

OLIVEIRA, António Cândido de. Direito das autarquias locais. Coimbra. Coimbra editora, 1993.

PAUPÉRIO, A. Machado. O município e seu regime jurídico no Brasil. $2^{a}$ ed., Forense: Rio de Janeiro, 1973.

RIVERO, Jean. Direito administrativo. Trad. Doutor Rogério Ehrhardt Soares. Coimbra: Almedina. 1981.

ROCHA, Cármen Lúcia Antunes. República e federação no Brasil: traços constitucionais da organização política brasileira. Belo Horizonte: Del Rey, 1997.

SILVA, José Afonso da. O município na Constituição de 1988. São Paulo: Editora Revista dos Tribunais. 1989.

. “Inovações municipais na Constituição de 1988”. RT, a. 80, vol. 669, julho de 1991, pp. 10-18.

. Curso de direito constitucional positivo. $13^{\mathrm{a}}$ ed., São Paulo: Malheiros, 2000.

SUNDFELD, Carlos Ari Vieira. "Regime Constitucional do Município". Revista da Procuradoria Geral do Estado de São Paulo, n. 34, dez. de 1990, pp. 45-70. 
TAVARES, José. Estudos jurídico-políticos. Lisboa: Universidade Autónoma de Lisboa, 1996.

TÔRRES, João Camillo de Oliveira. "O federalismo: formação histórico constitucional”. Revista de Ciência Política, vol. 3, n. 2, abr.jun. de 1969, pp. 21-51.

TRIGUEIRO, Osvaldo. “A crise do federalismo”, Revista Forense, a. 59, vol. 199, n. ${ }^{\text {os }} 709,710711$, jul./ago./set. de 1962, pp. 361-366.

VAMIREH, Chacon. "Federalismo aparente e unitarismo permanente no Brasil”, RBEP, n. 42, jan. de 1976, pp. 107-126. 